\title{
Kuosinvaihtoa vai uusia tuulia
}

Aikuiskasvatuksen käytännöt, tutkimus ja tieteellinen status ovat kaikkialla maailmassa entistä vakaammassa epävakauden tilassa. Yksittäisenä välähdyksenä tästä kuvaan kokemuksia eurooppalaisen aikuiskasvatuksen tutkimusseuran (ESREA) johtokunnan kokouksesta ja samaan aikaan järjestetyistä saksalaisen kasvatustieteen seuran vuotuisista päivistä Saksan Dresdenissä maaliskuun lopulla 2008. Paitsi että keli oli kurjempi kuin suomalai-

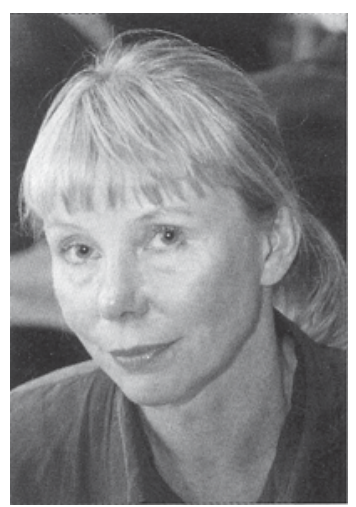

vastaisi esitysten tekemisestä. Ensimmäistä kertaa seuran historiassa päätettiin laatia eri toimintamuotoja koskeva "Action plan”, siis jonkinlainen toimintasuunnitelma, jonka mukaan myös taloudenpitoa arvioidaan. Keskustelua käytiin myös ESREAn yhteyksistä muihin verkostoihin ja järjestöihin, mutta linjausta ei toistaiseksi syntynyt, vain suositus tapahtumien päällekkäisyyden välttämisestä.

Jos ESREA aikanaan syntyikin nen olisi voinut odottaa lähtiessään loskaisesta pikkupakkasesta, Dresdenin näkymät muutenkin viestivät siitä, miten ajankohtainen taloudellinen haaste Länsi- ja Itä-Saksan yhdentyminen käytännön tasolla edelleen on.

ESREAn vuosiksi 2008-2010 valitun johtokunnan 12 jäsentä edustavat jokainen eri Euroopan maata, joten englantilaisten aiempi yliedustus tasapainottui nyt etelän suuntaan. Muutenkin ensimmäisessä kokouksessa puitiin ESREAn toiminnan lähtökohtia ja periaatteita sekä johtokuntatyöskentelyn käytänteitä. Keskustelu jatkuu, mutta näytti siltä, että 1980-luvun lopun sitoumuksia ja muotoutuneita rutiineja on syytä tarkistaa, mihin antaa hyvän mahdollisuuden myös sihteeristön siirtyminen Linköpingin yliopistoon ja Andreas Fejesin nuorekkaisiin käsiin. (Olin toki pettynyt oman yliopistoni ja suomalaisten aikuiskasvatustutkijoiden innottomuuteen pari vuotta sitten käydyssä sihteeristökilpailussa, mutta asioiden niin ja näin ollen ruotsalaisten valinta oli onnistunut ratkaisu ja Linköpingin yliopisto saa oikeutettua mainetta ja hyötyä aktiivisuudestaan.)

Seuran esihenkilönä jatkaa edelleen Henning Saling Olesen Roskilden yliopistosta ja varaesihenkilönä Ewa Kurantowics Ala-Sleesian yliopistosta. Valinnat eivät kuitenkaan olleet läpihuutojuttuja, vaan niiden yhteydessä selviteltiin puheenjohtajan, sihteeristön, johtokunnan jäsenten ja verkostojen vetäjien yhteistoiminnan pelisääntöjä, päätösten läpinäkyvyyden parantamista ja osallistavia toimintatapoja. Jo seuraavan kokouksen valmistelu päätettiin jakaa johtokunnan jäsenten kesken, jotta puheenjohtaja ja sihteeri eivät yksin hallinnon ja käytännön toimijoiden dominoiman verkostoitumisen vaihtoehdoksi, piti uuden johtokunnan enemmistö nykytilanteessa tärkeänä aikuiskasvatuspolitiikan ja -käytäntöjen muutosten seuraamista. Vaikka aikuiskasvatuksen poliittisen merkityksen lisääntymistä, toiminnan ja tutkimuksen laajenemista näyttää tapahtuvan erityisesti ammatillisen koulutuksen ja henkilöstön kehittämisen alueella, ovat johtokunnan vanhemmatkin jäsenet valmiita tutkimusprofiilin tarkistamiseen turvatakseen seuran jatkuvuuden ja "nuortumisen”.

Seuran keskeisin toimintamuoto ovat tutkimusverkostot, joiden aktiivisuus vaihtelee suuresti. Jatkossa sihteeristö ja verkostojen vetäjät koordinoivat yhdessä ja kukin johtokunnan jäsen seuraa joidenkin verkostojen toimintaa. Itseäni ilahdutti kreikkalaisen George Zafirisin esitys uuden aikuiskasvattajien kehitystä ja aikuiskasvattajuutta koskevan tutkimusverkoston perustamisesta. George kehittää muun muassa eestiläisen Larissa Jögin kanssa verkoston toiminta-ajatusta ja -suunnitelmaa seuraavaan johtokunnan kokoukseen ja

Toinen tärkeä toimintamuoto on julkaiseminen. Oman kirjasarjan julkaisemista Peter Lang-kustantamossa kritisoitiin muun muassa julkaisujen kalliiden hintojen takia, pidettiin parhaana kuitenkin jatkaa vasta käynnistynyttä toimintaa. Tärkeänä pidettiin, että kaikilla verkostoilla on mahdollisuus hyödyntää tätä julkaisukanavaa. Kiihkeämpi keskustelu käytiin jo vuosikaudet suunnitteilla olleesta omasta aikakauslehdestä. Eniten puhutti lehden sitoutuminen monikielisyyteen ja ei-anglofonisten ensimmäinen workshop pidetään vuonna 2009. 
tutkijoiden tukemiseen kirjoitusten englannintamisella. Tähän suunniteltiin rahoituksen hakemista EU:Ita ja järjestöiltä. Enemmistö kannatti myös lehden julkaisemista open access -periaatteella verkossa. Johtokunnan jäsenet jaettiin kahteen ryhmään asiaa valmistelemaan: toinen selvittelee tuotannollisia ja taloudellisia, toinen sisällöllisiä ja profiilia koskevia kysymyksiä. Samaan aiheeseen liittyi päätös ottaa junioritutkijat entistä näkyvämmin huomioon, paitsi verkostojen ja konferenssien järjestelyjen, myös julkaisutoiminnan yhteydessä.

Suurien suunnitelmien toteuttamiseksi ladattiin paljon odotuksia kotisivuihin, postituslistaan ja yhteyksiin jäsenistöön. Toivottavaa on, että kiinnostuneet voisivat entistä vaivattomammin seurata ESREAn johtokunnan ja verkostojen toimintaa, tehdä aloitteita ja vaikuttaa seuran tulevaisuuteen. ESREAn ja ATS:n kotisivuosoitteet kannattaakin laittaa muistiin työpöydän suosikkeihin. http://www.esrea.org/ ja http://www.protsv.fi/ats/

Dresdenissä järjestettiin samaan aikaan Saksan kasvatustieteellisen seuran (DGfE, http://www. dgfe.de/, mistä löytyy myös kongressin materiaalia) joka toisvuotinen kongressi. Se toi mieleeni jälleen yhteistyöajatuksen, jota olen yrittänyt syöttää suomalaiseen kasvatustieteiden tutkijakenttään. Saksassa kaikki kasvatustieteiden osa-alueet sopivat siististi emoseuran yhteyteen, vaikka ne järjestävät myös itsenäisinä sektioina omaa toimintaansa. Järjestely esimerkiksi säästää resursseja, antaa kasvatustieteilijöiden kannanotoille kuuluvuutta ja näkyvyyttä ja edistää kasvatustieteilijöiden keskinäistä tuntemusta toisistaan. Onko
Suomi niin iso maa vai meneekö kasvatustieteilijöillä niin hyvin, että meillä on varaa organisoitua lukuisiin erillisiin seuroihin ja pitää eri tutkimusdiskurssit poteroissaan, vaikka seurojen aktiivit ja aktiiviset tutkijat tuppaavat olemaan samaa porukkaa? Jos meillä jokaisella olisi rahaa ja voimia osallistua kaikkiin pippaloihin, jäisikö niitä enää kansainväliseen toimintaan?

Tällä kertaa saksalaisen kongressin aiheena oli Kulturen der Bildung, joka läpäisi kaikkien sektioiden työryhmiä. Itse ehdin osallistua ammattikasvatussektion oppisopimuskulttuurien vertailua sekä kulttuurisia kompetensseja koskeviin työryhmiin - ja tietysti aikuiskasvatussektion aikuiskasvatuksen tutkimuskulttuureja käsittelevään työryhmään, jonka runkona olivat ESREAn johtokuntalaisten alustukset. Vaikka demonstratiivinen tietotekniikan näkymättömyys välillä ärsyttikin yliopistossa, joka sentään on säilyttänyt legendaarisen Dresdenin teknillisen yliopiston nimen, oli saksalaisen konferenssikulttuurin haistelu vaihteeksi mukavaa. Alustuksille annetaan aikaa, ne ovat usein teoreettisesti vaativia ja harvoin yleisöä kosiskelevia, keskustelu on perusteellista ja päättyy puhutun asiantuntevaan yhteenvetoon. Saksalainen koordinointitaito ei sen sijaan ollut tapahtumassa parhaimmillaan: kovin monet samanaiheiset työryhmät oli ajoitettu päällekkäin, mikä vei yleisöä myös englanninkieliseltä ESREA-sessiolta. Paikalla olleille keskustelu kyllä kirkasti tarvetta ESREAn luonteen ja toiminta-ajatuksen pohtimiseen jatkossa.

Anja Heikkinen 